\title{
Jurnal

\section{PENGARUH TERAPI AUDIOVISUAL (FILM KARTUN) TERHADAP TINGKAT STRES PADA ANAK USIA SEKOLAH YANG MENJALANI PHYSICAL DISTANCING DI RW 01 DESA WAGE KECAMATAN TAMAN KABUPATEN SIDOARJO}

\section{The effect of audiovisual therapy (cartoon film) on the level of stress in school-age children undergoing physical distancing}

\author{
Putri Novitasari, Dwi Ernawati, Sapto Dwi Anggoro
}

\author{
Sekolah Tinggi Ilmu Kesehatan Hang Tuah Surabaya
}

\section{Riwayat artikel \\ Diajukan: 26 Desember 2020}

Diterima: 17 Februarai 2021

Penulis Korespondensi:

- Dwi Ernawati

- Sekolah Tinggi Ilmu Kesehatan Hang Tuan Surabaya

e-mail:

dwiernawati@stikeshangtu ah-sby.ac.id

\section{Kata Kunci:}

Stres, physical distancing, anak usia sekolah, terapi audiovisual.

\section{Abstrak}

Pendahuluan : Physical distancing adalah salah satu cara untuk mencegah penularan dan memutus rantai penyebaran Covid-19. Saat ini seluruh kegiatan anak usia sekolah harus berada di dalam rumah, sehingga mereka mengeluh bosan karena tidak bisa bermain dengan temannya hal ini juga bisa mengakibatkan anak mengalami stres. Salah satu cara untuk mengurangi stres yaitu terapi audiovisual. Tujuan: Untuk meneliti pengaruh terapi audiovisual terhadap tingkat stres pada anak usia sekolah yang menjalani physical distancing di RW 01 Desa Wage Kecamatan Taman Sidoarjo. Metode: Desain penelitian ini menggunakan desain penelitian Quasy-Eksperimental dengan metode pre-test - post test control group. Sampel penelitian ini berjumlah 50 anak, yang dibagi menjadi 25 anak pada kelompok intervensi dan 25 responden pada kelompok kontrol dengan menggunakan teknik Simple Random Sampling. Alat ukur yang digunakan adalah kuesioner melalui googleform. Analisa data menggunakan Wilcoxon Signed Rank dan uji Mann-Whitney $(\rho \leq 0.05)$. Hasil: Hasil penelitian menunjukkan bahwa ada pengaruh terapi audiovisual (film kartun) terhadap tingkat stres pada anak usia sekolah yang menjalani physical distancing dengan derajat signifikan $\rho \leq 0,05$. Kesimpulan: Implikasi penelitian ini adalah untuk menurunkan stres pada anak usia sekolah yang menjalani physical distancing dengan melakukan terapi setiap hari selama satu episode film kartun.

\section{Abstract}

Background: Physical distancing is a way to prevent transmission and disconnecting the Covid-19 spread chain. Currently, all the activities of school-age children must be at home. These activities make children bored because they cannot play with their friends, this can also cause the child to experience stress. One way to reduce stress is audiovisual therapy. Objective: This research aims to examine the influence of audiovisual therapy on the level of stress in school-age children undergoing physical distancing in the RW 01 at the Wage Village, Taman District, Sidoarjo. Method: The design of this research used the Quasy-Experimental research design with a pre-test-post test control group method. The research samples were 50 children, which were divided into 25 children in the intervention group and 25 respondents in the control group using the Simple Random Sampling technique. The measuring instrument used a questionnaire through Google form. Data analysis used Wilcoxon Signed Rank and Mann-Whitney test $(\rho \leq 0.5)$. Results: The results had an effect of audiovisual therapy (cartoon film) on the level of stress in school-age children undergoing physical distancing with a significant degree $\rho$ $\leq 0.05$. Conclusion: The implications of this research suggest that watching cartoon films could be accepted as an appropriate therapy for school-aged children to reduce stress. 


\section{PENDAHULUAN}

Interaksi sosial merupakan hal yang sering dilakukan oleh manusia. Sebagian besar orang tua selalu mengajarkan anak nya untuk bersosialisasi sejak dini dengan orang lain. Salah satu bentuk sosialisasi pada anak usia sekolah yaitu dengan cara bermain. Bermain dengan teman sebaya maka anak akan berinteraksi dengan temannya. Tetapi dengan adanya pandemi yaitu Covid-19, maka seluruh manusia diharapkan untuk menjaga jarak (physical distancing) secara fisik bertujuan mencegah terjadinya penyebaran Covid-19. Physical distancing yaitu memberi jarak >1,5 2 meter dari seseorang serta menjauhi keramaian demi memutus rantai penyebaran dan mencegah penularan Covid-19 (Kemenkes, 2020). Fenomena Covid-19 yang terjadi saat ini, pemerintah memberlakukan physical distancing agar masyarakat dapat mencegah dan memutus rantai penyebaran virus yang ditularkan melalui sentuhan fisik dan droplet dari orang yang terkena Covid-19. Sehingga masyarakat harus tinggal dirumah sampai waktu yang tidak dapat ditentukan. Anak usia sekolah yang biasanya melakukan kegiatan di luar rumah dan di sekolah dengan temannya. Saat ini seluruh kegiatan anak harus berada di dalam rumah, sehingga mereka mengeluh bosan karena tidak bisa bermain dengan temannya.

Data statistik menunjukan bahwa seluruh negara yang terdampak kasus virus corona. (WHO, 2020) mendeskripsikan bahwa kasus virus corona sudah menyebar di 206 negara menunjukan bahwa ada 900.306 kasus di dunia dan 45.693 orang dinyatakan meninggal dunia. Pada tanggal 07 April 2020 Pemerintah Indonesia melalui Satuan Tugas Penindakan kasus Covid-19 mengagendakan total pasien Covid-19 yang sudah pulih di Indonesia menjadi 81 pasien, sedangkan kasus konfirmasi Covid-19 bertambah menjadi 1.528 orang dan kasus yang meninggal dunia bertambah 14 sehingga meninggal dan 75 orang sembuh (BNPB, 2020). Komisi Nasional Perlindungan Anak mendapatkan informasi bahwa terdapat rata-rata 200 kasus perbulannya, kasus ini melonjak $98 \%$ dari sebelumnya. Laporan tersebut menunjukan terdapat penambahan tanda dan gejala pada anak yang mengalami stres di Negara ini. PDPG menyebutan rata-rata anak usia $\pm 2-15$ tahun akan merasakan stres, $40 \%$ dialami bayi lima tahun dan sisanya $60 \%$ dialami oleh anak usia sekolah. Data studi pendahuluan di RW 01 Desa Wage- TamanSidoarjo dengan berjumlah 20 siswa menunjukan bahwa kurang lebih $75 \%$ anak mengalami stres karena terlalu banyak tugas pekerjaan rumah data tersebut didaptkan dari hasil pengisian kuisioner pada poin ke 14 dengan pertanyaan " saya senang mendapatkan pekerjaan rumah dari guru" 15 anak menjawab "tidak pernah" dan $25 \%$ mengatakan senang karena berada di dalam rumah, data tersebut didapatkan dari hasil pengisian kuisioner pada poin ke 13 dengan pertanyaan "saya suka berada di dalam rumah" 5 anak menjawab selalu.

Kondisi di Indonesia saat ini dengan adanya pandemi Covid-19, maka anak sekolah dihimbau untuk belajar di rumah. Seluruh sekolah mengumumkan bahwa siswa harus belajar di rumah untuk mengurangi angka kejadian Covid-19 di Indonesia. Saat ini siswa diberikan tugas oleh guru untuk dikerjakan dirumah dan tidak diperbolehkan untuk melakukan kegiatan lainnya dengan teman sebayanya. Anak sering marah-marah karena sudah merasa bosan berada di rumah terus menerus dan ingin bermain dengan temannya sehingga anak mengalami perasaan yang tertekan atau biasa disebut dengan stres. Stres pada anak usia sekolah terdapat dampak negatif dalam menjalani physical distancing yaitu anak merasa kesepian, kurangnya produktivitas dan kehilangnya manfaat lain yang berkaitan berinteraksi dengan masyarakat.

Upaya dapat dilakukan agar anak yang mengalami physical distancing mengalami penurunan tingkat stres. Beberapa terapi tersebut seperti : terapi musik, terapi audiovisual, terapi bermain puzzle, terapi bermain mewarnai, ada juga teknik berkomunikasi secara terapeutik dan teknik mengalihkan perhatian atau distraksi. Perpaduan antara memusatkan perhatian melalui pendengaran atau audio dan melalui penglihatan atau visual disebut dengan memusatkan perhatian terhadap audiovisual, terapi tersebut bermanfaat untuk memindahkan perhatian pada anak agar kecemasan atau ketakutan menurun, rasa tidak nyaman dan tingkat stres. Pada anak yang menjalani physical 
distancing dengan cara memberikan terapi audiovisual berupa animasi dan lagu karena tingkat imajinasi pada anak usia tersebut cukup tinggi.

Manfaat dari terapi distraksi audiovisual yaitu untuk melepaskan hormon endorphin yang berfungsi untuk mengurangi stress dan mengurangi rasa sakit. Reaksi pada anak saat menjalani physical distancing yaitu rasa cemas, stress dan perubahan perilaku pada anak (Lilis Fatmawati, Yuanita Syaiful, 2019).

Anak yang saat ini sedang menjalani physical distancing sebagian besar mengalami stres. Adapula cara yang efektif untuk mengurangi stres pada anak yang menjalani physical distancing yaitu dengan melakukan terapi audiovisual misalnya menonton film kartun yang disukai oleh anak tersebut selain itu orang tua harus menciptakan lingkungan yang nyaman dan memodifikasi rumah menjadi tempat yang di senangi oleh anak -anak agar anak tidak merasa bosan saat berada di rumah. Karena salah satu fungsi dari terapi audiovisual adalah menurunkan stres dan membuat anak menjadi rileks. berdasarkan uraian diatas maka penulis menarik untuk mengambil judul " Pengaruh Terapi Audiovisual (Film Kartun) terhadap Tingkat Stres Anak Usia Sekolah yang menjalani physical distancing di RW.01 Ds. Wage Kec. Taman Kab. Sidoarjo".

\section{METODE}

Jurnal penelitian yang menurut saya sesuai dengan kriteria insklusi kemudian dikumpulkan dan dibuat rangkuman dari jurnal yang meliputi nama penulis, tahun terbit jurnal, rancangan studi, tujuan penelitian tersebut, sampel instrument atau alat ukur dan rangkuman hasil atau penemuan. Rangkuman jurnal dari penelitian tersebut dimasukkan kedalam tabel kemudian di susun sesuai alfabet dan tahun diterbitkan jurnal sesuai dengan format tersebut diatas. Agar lebih memperjelas analisis dalam abstrak dan isi jurnal maka mudah dibaca dan dicermati dengan seksama. Rangkuman jurnal kemudian dianalisis terhadap isi yang terdapat dalam tujuan penelitian. Metode analisa data yang digunakan yaitu analisis jurnal.

\section{HASIL DAN PEMBAHASAN}

\section{HASIL \\ 1.Karakteristik Responden Berdasarkan Jenis Kelamin}

Tabel 1 Karakteristik responden berdasarkan usia pada kelompok intervensi dan kontrol di RW 01 Desa Wage Kecamatan Taman Sidoarjo, Mei $2020(n=50$ anak)

\begin{tabular}{|c|c|c|c|c|c|}
\hline \multirow[t]{2}{*}{$\begin{array}{l}\mathbf{N} \\
\mathbf{0}\end{array}$} & \multirow{2}{*}{$\begin{array}{l}\text { Jenis } \\
\text { Kela } \\
\text { min }\end{array}$} & \multicolumn{2}{|c|}{$\begin{array}{l}\text { Kelompok } \\
\text { Intervensi }\end{array}$} & \multicolumn{2}{|c|}{$\begin{array}{c}\text { Kelompok } \\
\text { Kontrol }\end{array}$} \\
\hline & & $\begin{array}{c}\text { Juml } \\
\text { ah }\end{array}$ & $\begin{array}{c}\text { Persent } \\
\text { ase }\end{array}$ & $\begin{array}{c}\text { Juml } \\
\text { ah }\end{array}$ & $\begin{array}{c}\text { Persent } \\
\text { ase }\end{array}$ \\
\hline 1. & $\mathrm{~L}$ & 10 & 40 & 9 & 36 \\
\hline 2. & $\mathrm{P}$ & 15 & 60 & 16 & 64 \\
\hline \multicolumn{2}{|c|}{ Total } & 25 & 100 & 25 & 100 \\
\hline
\end{tabular}

Tabel 1 menunjukkan bahwa responden yang gender laki-laki dan gender perempuan dalam dua kelompok tersebut, yaitu kelompok intervensi\&kontrol. Pada kelompok intervensi didapatkan sebagian besar responden dengan gender perempuan $60 \%$ dan berjenis kelamin laki-laki $40 \%$, sedangkan pada kelompok kontrol yang didapatkan berjenis kelamin perempuan $64 \%$ dan berjenis kelamin laki-laki $36 \%$.

\section{Karakteristik Responden Berdasarkan Sekolah}

Tabel 2 Karakteristik responden berdasarkan sekolah di RW 01 Desa Wage Kecamatan Taman Sidoarjo, Mei 2020 ( $\mathrm{n}=50$ anak)

\begin{tabular}{lccccc}
\hline No & $\begin{array}{c}\text { Nama } \\
\text { Sekolah }\end{array}$ & \multicolumn{2}{c}{ Kelompok Intervensi } & \multicolumn{2}{c}{$\begin{array}{c}\text { Kelompok } \\
\text { Kontrol }\end{array}$} \\
\cline { 3 - 6 } & & Jumlah & $\%$ & Jumlah & $\%$ \\
\hline 1. & SDN & 15 & 60 & - & - \\
2. & Wage & 10 & 40 & - & - \\
3. & MI Al- & - & - & 14 & 56 \\
4. & Qodir & - & - & 11 & 44 \\
& SDN & - & & & \\
& Bangah & & & & \\
& SDN & & & & \\
\hline & Pepelegi & & 100 & 25 & 100 \\
\hline
\end{tabular}

Tabel 2 menunjukan sekolah responden pada kelompok intervensi yang didapatkan 
responden yang bersekolah di SDN Wage sebanyak $60 \%$, dan responden yang bersekolah di MI-Al Qodir sebanyak $40 \%$. Sedangkan pada kelompok kontrol responden bersekolah di SDN Bangah sebanyak $56 \%$ dan responden yang bersekolah di SDN Pepelegi sebanyak 44 $\%$.

\section{Hasil Data Khusus}

\section{Pengaruh Terapi Audiovisual (Film} Kartun) Terhadap Tingkat Stres

Tabel 3. Hasil Uji Mann-Whitney Tingkat Stres di RW 01 Desa Wage Kecamatan Taman Sidoarjo, Mei 2020 ( $n=50$ anak)

\begin{tabular}{lccc}
\hline No & Kelompok & Mean & SD \\
\hline 1. & Intervensi & 19,52 & 488 \\
\hline 2. & Kontrol & 31,48 & 787 \\
\hline
\end{tabular}

Berdasarkan hasil uji statistik Mann Whitney mean hasil tingkat stres sebelum pada kelompok intervensi \& kontrol adalah 19,52 dan 31,48 dengan SD 488 pada bagian intervensi dan 787 pada bagian kontrol. Hasil uji statistik $\mathrm{P}=0,004$ artinya ada perselisihan bermakna diantara 2 kelompok yaitu kelompok intervensi\&kelompok kontrol.

Tabel 4. Hasil Uji Wilconxon Signed Rank Tingkat Stres di RW 01 Desa Wage Kecamatan

Taman Sidoarjo, Mei 2020 ( $n=50$ anak)

\begin{tabular}{cccccc}
\hline No & Kelompok & Mean & SD & $\begin{array}{c}\text { P } \\
\text { Value }\end{array}$ & N \\
\hline 1. & Pre & 49,93 & 1.275 & 0,008 & 50 \\
& intervensi & & \\
dan Post & & & & \\
intervensi & & & & \\
terapi \\
audiovisual \\
(film \\
kartun)
\end{tabular}

Berdasarkan dari hasil uji statistik Wilcoxon Signed Rank Test, sebelum dan sesudah diberikan intervensi maka rata-rata tingkat stres rata-rata tingkat stres anak adalah 49,93 dan dan diketahui hasil uji statistik $\mathrm{P}$ Value adalah 0,008 maka dinyatakan bahwa hipotesis di terima, yaitu terdapat perbedaan antara sebelum dan sesudah diberikan tes, maka bisa diartikan hasilnya terdapat pengaruh terapi audiovisual (film kartun) terhadap tingkat stres pada anak usia sekolah yang menjalani physical distancing.

\section{PEMBAHASAN}

Tingkat stres yang dialami anak usia sekolah yang menjalani physical distancing mengalami penurunan tingkat stres setelah diberikan terapi audiovisual dengan menonton film kartun. Sebelumnya terdapat $60 \%$ yang mengalami stres sedang dan $40 \%$ mengalami stres ringan dan setelah diberikan terapi audiovisual dengan menonton film kartun maka terdapat $84 \%$ mengalami stres ringan dan $16 \%$ sudah tidak mengalami stres. Perubahan ini membuktikan bahwa terapi audiovisual dengan menonton film kartun ada pengaruh terhadap tingkat stres padaanak usia sekolah yang menjalani physical distancing. sedangkan pada kelompok kontrol yang diberikan pre-test didapatkan responden dengan tingkat stres sedang sebanyak $32 \%$ dan tingkat stres ringan sebanyak $68 \%$ dan pada saat dilakukan post-test didapatkan sebagian besar responden tingkat stres ringan sebanyak $32 \%$ dan tingkat stres sedang sebanyak $68 \%$. Perubahan tersebut tingkat stres pada anak semakin meningkat jika tidak diberikan terapi audiovisual.

Pada kelompok intervensi didapatkan sebagian besar responden dengan jenis kelamin perempuan $60 \%$ dan berjenis kelamin laki-laki $40 \%$, sedangkan pada kelompok kontrol yang didapatkan berjenis kelamin perempuan $64 \%$ dan berjenis kelamin laki-laki $36 \%$. Berdsarkan asal sekolah responden pada kelompok intervensi yang didapatkan responden yang bersekolah di SDN Wage sebanyak $60 \%$, dan responden yang bersekolah di MI-Al Qodir sebanyak $40 \%$. Sedangkan pada kelompok kontrol responden bersekolah di SDN Bangah sebanyak $56 \%$ dan responden yang bersekolah di SDN Pepelegi sebanyak $44 \%$.

Hasil dari uji Wilcoxon Signed Rank Test memperoleh nilai $\mathrm{P}$ Value $=0,008 \quad(<0,05)$ menunjukkan hasil hipotesis diterima, berarti terdapat pengaruh yang relevan antara terapi audiovisual (film kartun) dan tingkat stres pada anak yang saat ini berusia sekolah yang 
menjalani physical distancing di RW 01 Desa Wage Kecamatan Taman Sidoarjo.

Penelitian yang dilakukan (Utami, 2014), Sebagian besar anak sangat rentan menghadapi situasi yang membuat stres. Hal tersebut di karenakan kondisi koping pada anak belum berkembang secara sempurna. Stres yang dialami oleh anak tidak semata-mata langsung terjadi tetapi ada stressor yang mempengaruhi. Stressor yang dihadapi oleh seseorang akan diterima di otak dan disalurkan melalui akson dan kelenjar pituitari yang menghasilkan hormon oksitosin dari neuron dalam hipotalamus yang dapat mempengaruhi sistem saraf simpatik. Hipotalamus merupakan bagian dari otak yang berfungsi penting dalam mengatur proses homeostatis seperti untuk mengatur emosi.

Besar kecilnya respon stres bukan hanya bergantung pada pada stressor dan individunya. Respon stres yang bervariasi, respon tepatnya bergantung pada stressornya, kapan waktu stres terjadi, sifat stres yang dialami seseorang dan mekanisme reaksi stres pada stresornya (Pinel, 2012). Menurut teori (Goldman, 2012) audiovisual dengan cara menonton film kartun merupakan proses terbentuknya imajinasi, menangkap informasi, memberikan edukasi dan hiburan agar dapat memberikan ekspresi perasaannya.

Sebagian besar anak-anak menyukai film kartun menggunakan unsur kartun animasi. Unsur-unsur tersebut dan emosional dalam film animasi adalah unsur otak bagian kanan \& unsur otak bagian merupakan suara yang timbul dari film tersebut. Unsur grafis yang disarankan pada anak usia sekolah adalah unsur terpenting dikarenakan pada anak usia sekolah unsur audio dan ekspresi sebagai akibatnya menerima perhatian sebanyak $98 \%$ dan $2 \%$ terdapat dalam unsur visual statis (Wahyuningrum, 2015). Akhirnya anak usia sekolah yang menonton film kartun animasi misalnya Si Kancil, Nussa Rara ataupun The Little Tayo, dalam otak kanan\&otak kiri pada anak dipakai ketika bersamaan maka semuanya seimbang dan anak terdapat penekanan pada film kartun (Wahyuningrum, 2015)

Manfaat mempersembahkan visual (gambar yang tidak bergerak) dan video (gambar yang bergerak) maka masih ada peningkatan pemusatan perhatian pada anak dan dapat memberikan kemudahan untuk pembelajaran (Febriana, D., \& Wahyuningsih, 2011). Terapi audiovisual diberikan untuk anak yang mengalami stres dan terapi audiovisual merupakan cara efektif untuk menghilangkan perhatian anak dari suatu objek yang dapat membuat mereka stres. Pembahasan di atas dapat disimpulkan bahwa terapi audiovisual terhadap tingkat stres pada anak usia sekolah yang menjalani physical distancing memberikan pengaruh terhadap perubahan tingkat stres anak.

\section{KESIMPULAN}

Terapi audiovisual menonton film kartun mempengaruhi tingkat stres pada anak usia sekolah yang saat ini sedang menjalani physical distancing di RW 01 Desa Wage Kecamatan Taman Sidoarjo.

\section{IMPLIKASI}

Orangtua dapat menerapkan Terapi audiovisual menonton film kartun untuk menurunkan stress anak sekolah yang melakukan pembelajaran di rumah pada masa pandemic Covid 19.

\section{DAFTAR PUSTAKA}

BNPB (2020) sebanyak 81 pasien sembuh dan 1528 positif covid19 di indonesia. Available at: https://bnpb.go.id/berita/sebanyak-81pasien-sembuh-dan-1-528-positif-covid19di-indonesia.

Febriana, D., \& Wahyuningsih, A. (2011) 'Kajian Stres Hospitalisasi Terhadap Pemenuhan Pola Tidur Anak Usia Prasekolah di Ruang Anak RS Baptis Kediri', Journal STIKES RS. BAPTIS KEDIRI, 4(2), pp. 66-72.

Goldman, K. \& (2012) 'Pediatric Psychosocial Oncology: Textbook for Multidisciplinary Care', USA: Springer.

Kemenkes (2020) 'Corona Virus di Indonesia'. Lilis Fatmawati, Yuanita Syaiful, D. R. (2019) 'Pengaruh Audiovisual Menonton Film Kartun Terhadap Tingkat Kecemasan Saat Prosedur Injeksi Pada Anak Prasekolah', Pengaruh Audiovisual Menonton Film Kartun Terhadap Tingkat Kecemasan Saat Prosedur Injeksi Pada Anak Prasekolah, 12, 
pp. 15-29.

Pinel, J. P. J. (2012) 'Stres dan Kesehatan Dalam: Biopsikologi', edition 7.

Utami, Y. (2014) 'Dampak hospitalisasi terhadap perkembangan anak', 2 .
Wahyuningrum (2015) 'Pengaruh Cerita Melalui Audiovisual', Studi Ilmu Keperawatan.

WHO (2020) 'Coronavirus Disease'. 